\title{
The Implementation of Criminal Law as a Primum Remedium in Overcoming Criminal Crime and Or Environmental Damage
}

\author{
Herlyanty Y. A. Bawole ${ }^{1^{*}} \quad$ I Nyoman Nurjaya ${ }^{1} \quad$ Grace Yurico Bawole $^{2} \quad$ Yulianty Sanggelorang $^{3}$ \\ 1.Faculty of Law, Brawijaya University, Jl. M. T. Haryono No. 169, Malang 65147, Indonesia \\ 2.Faculty of Law, Sam Ratulangi University, Jl. Kampus Bahu Unsrat, Manado 95115, Indonesia \\ 3.Faculty of Public Health, Sam Ratulangi University, Jl. Kampus Bahu Unsrat, Manado 95115, Indonesia
}

\begin{abstract}
This study aims to analyze and describe the definition and the meaning of the primum remedium principle as an instrument to overcome the crime. The research method used is normative legal research by studying the laws, concepts and various approaches in conducting the research. The legal materials used are statutory regulations, books, glorosium, encyclopedias and others. The results showed that the meaning of primum remedium as an instrument for tackling criminal acts is to increase awareness of the development of human rights that bring changes to criminal responsibility which is no longer ultimum remedium but primum remedium. Republic of Indonesia Law Number 32 Year 2009 concerning Environmental Protection and Management Life is a legal instrument that was formed to protect the country in terms of the environment. Therefore it is a necessity for all humans to create a healthy, clean and insightful environment, because people's awareness of the environment is part of human rights. Thus it cannot be denied that the role of government is needed in upholding justice because it has an important role to create a conducive political system or structure, which changes the paradigm of criminal justice which is subsidiary becoming the primum remedium.
\end{abstract}

Keywords: Ultimum Remedium, Primum Remedium

DOI: $10.7176 / \mathrm{JLPG} / 89-10$

Publication date:September $30^{\text {th }} 2019$

\section{Introduction}

In the past half century or seventy-one years ago, our country, the state of Indonesia, had become independent. The founders of the state have mandated that the Indonesian country is based on law that has the objectives as stated in the Preamble to the 1945 Constitution of the Republic of Indonesia, namely: "Protect all Indonesians and all Indonesian blood, and to advance the general welfare, enhance the life of the nation, and participate in carrying out world order based on eternal peace and social justice which is based on Pancasila." It is the national goal of our country and at the same time, it is the foundation and the basis of the state. ${ }^{1}$

Since the independence of the Republic of Indonesia, the state has been developing nationally. However, a few years later the Indonesian nation experienced a monetary and economic crisis, and it has expanded to reach all aspects of the nation's life including political, economic, social, and others that have resulted in irregular economic and financial order, widespread unemployment and poverty which lead to powerlessness society, and various crimes or criminal acts that are occured and felt by all levels of society including environmental crimes. According to historical journey in Indonesia from independence to the present, citizens often experience various kinds of disruption that damages and disturbs the welfare of the community, whether it is a disturbance to the self, family, or as a group of community members from various forms of evil or criminal acts.

Therefore, the relevant authorities always make various efforts in the form of policies which can prevent and cope with acts that can disrupt the welfare of the community both in the form of making laws and regulations, as well as implementing and applying them to the perpetrators. One of which to strive is to provide a deterrent effect for pollutants and environmental destroyers which is very detrimental to the surrounding community. Humanity's concern for the environment is a global concern for human interests, because the impact is not only limited locally, but often has a global impact. The development and the environment have been seen as two things that are always contradictory. The problem is that development pursued through industrialization often raises environmental problems in the form of environmental destruction and pollution. ${ }^{2}$

Indonesia as a country that recognizes the value of the universality of human rights ${ }^{3}$, has an obligation to

\footnotetext{
${ }^{1}$ Amsyari, F., Prinsip-prinsip Masalah Pencemaran Lingkungan, Ghalia Indonesia,

2 The development is often interpreted as implementing certain changes to a community. It is often also stressed that the nature of development is towards people. This general understanding contains a dual nature. On the one hand it emphasizes development orientation but on the other hand, it ignores the fact that development is not just a change in a society but also in its environment. See Hakim, A., Legal Uses in Prevention, Environmental Pollution due to Industrial Waste, LIPI, Jakarta, 1992, p. 5

${ }^{3}$ As known, that in this century, in any hemisphere, human rights have become a written legal concept. In England known as Magna Charta 1215 Hobeas Corpus Act 1679, and Bill of Rights 1689, which gave rise to the view that humans have the same rights before the law and also gave birth to the principle of equality. The next development was marked by the emergence of The American Declaration of Independence which specifically wrote that man was free from the stomach of his mother, so it is not logical that after birth, humans must be bound, see Agung Wardana, Perusakan Lingkungan Sebagai Pelanggaran HAM, article 2007, p. 2
} 
protect, to respect, and to fulfill the basic rights of its citizens, namely education, welfare, health, employment, security, clothing, a good and healthy environment. But in fact the quality of life of the people actually experienced a decline. The basic right to life has been threatened by environmental destruction, deforestation, water and air pollution, deprivation of people's livelihoods (agrarian and natural resources).

Subhi Mahmassani stated that human rights basically refer to the principle of social responsibility and social justice which is composed of the principle of justice and it is equipped with the principle of balance and virtue, which ultimately meets the highest values or ideas taught by religion and morals. ${ }^{1}$ Based on the conception of human rights, it is very relevant if the author states that the right to the environment as part of natural human rights is a gift from God to mankind. Therefore it is also very relevant if theories or teachings on human rights are related to various violations in the environmental field, which should be interpreted as a threat to human civilization. Related to human rights over the environment, by placing the state as a stronghold of human rights, then in the management of natural resources and the environment, the people must be placed as the primary interest. The state fully plays the role of management and organizer of policies aimed at protecting and promoting human rights for the environment. ${ }^{2}$ The understanding of the right to control the state over the branches of production that are important to the state and control the livelihoods of many people for the full prosperity of the people, has legitimacy when shown to the interests of the rights of its citizens. The interests of the people or people's human rights, especially in terms of access to natural resources and the environment must be made as the main means and the ultimate goal of the right to control the state, as referred to in article 33 paragraph (3) of the 1945 Constitution.

In the consideration "in letter a" Law No. 32 of 2009 concerning Environmental Protection and Management - Undang-undang Perlindungan dan Pengelolaan Lingkungan Hidup (UUPPLH) states that: "A good and healthy environment is the human right of every Indonesian citizen as mandated in article $28 \mathrm{H}$ of the 1945 Constitution of the Republic of Indonesia." In article 3 of the UUPPLH, it is stated that the protection and management of the environment aims: a. protect the territory of the Unitary State of the Republic of Indonesia from environmental pollution and or damage; b. Ensure safety, health and human life; c. Guarantee the survival of living things and the preservation of ecosystems; d. Maintain environmental functions; e. Achieve harmony, suitability, and environmental balance; f. Guarantee the fulfillment of the justice of present and future generations; g. Ensure the fulfillment and protection of the right to the environment as part of human rights; $h$. Controlling the wise use of natural resources; i. Achieve sustainable development; and J. Anticipating global environmental issues.

In the Consideration of Law No. 39 of 1999 concerning Human Rights, stated that humans as creatures of God Almighty who have the task of managing and maintaining the universe with full devotion and full responsibility for the welfare of humanity, by its creator, was awarded human rights to ensure the existence of dignity and nobility of himself and the harmony of the environment. Dealing with the right to the environment, it is clearly stated in Article 9 paragraph (3) which states: "Everyone has the right to a good and healthy environment". Thus it is clear that the right to the environment is a human right, not only must be recognized and respected, but must also be upheld.

Polluting and causing damage to the environment are activities that can endanger the human life and soul. Criminal law basically aims to "protect the lives and honor of humans and property". However, at the time the Criminal Code - Kitab Undang-undang Hukum Pidana (KUHP) was compiled, environmental problems were not yet a problem that often occurred and it was not a problem that could threaten the survival of individuals or communities because the industry had not developed as rapidly as happened today.

Therefore, a special law was drafted in which it regulates the environment with criminal sanctions outside the Criminal Code. Starting with Law Number 4 of 1982, Law Number 23 of 1997, and Law Number 32 of 2009. UUPPLH regulates criminal liability for perpetrators of pollution and environmental damage. The Environmental Protection and Management Act or UPPLH currently provides a new legal position for criminal sanctions that is no longer a "final drug" but as a "primary drug" known as primum remedium. In contrast to Law Number 23 of 1997, Law Number 32 of 2009 more emphasises on the application of the primum remedium principle while still paying attention to the ultimum remedium principle.

The problem is "What is the meaning of primum remedium as an instrument to deal with criminal acts?" This will be answered in the discussion of this paper.

\section{Methodology Of Research}

The research method is a procedure or step or a technique to answer existing problems. Therefore the use of research methods should always be adjusted to the needs of researchers themselves. Thus, they do not experience

\footnotetext{
${ }^{1}$ Subhi Mahmassani, Konsep Dasar Hak- hak Asasi Manusia, Suatu Perbandingan Dalam Syariat Islam dan Perundang- undangan Modern, Tinta Mas, Jakarta, 1993, p. 206

${ }^{2}$ See and compare with Dadang Sudarja, Reformasi Pengelolaan Lingkungan Hidup, article, On the discussion of Building the Skepo Environmental Movement, Walhi, 2007, p. 1-3
} 
any difficulty in gathering legal material, and comparative studies in the field as a comparison.

The research used is the type of normative legal research or library research which examines the conceptualized law as an applicable norm in the form of norms or positive legal norms. ${ }^{1}$ Furthermore, the research method is used in accordance with the formulation of the problem that is the focus of this study, namely Environmental Criminal Law. Normative research methods open up opportunities for historical approaches by examining the background and development of the use and regulation of government coercive sanctions in the UUPPLH. The method used is a qualitative approach in legal research, especially in juridical studies more effective in obtaining a complete and in-depth picture of law in society, especially in criminal liability as primum remedium.

Legal research is conducted to produce new arguments, theories or concepts as a perscription in solving the problem at hand. This type of normative legal research is a type of research that will be used in finding, collecting and processing legal materials. This type of research was chosen because in this dissertation the legal material will be the basis of the policy problem of the need for efforts to use criminal law as primum remedium in enforcing "criminal acts of pollution and or environmental destruction". Therefore, normative legal research lies in the study of law or legal review (rechtsboefening) of positive law which includes three layers of legal scholarship consisting of law dogmatic, legal theory, and legal philosophy.

For the dogmatic layer of the law, the study was carried out on the identification of legal protections that were just, legal certainty, useful in positive law in particular presenting the provisions of national legislation which focused more on the use of criminal law as the first and foremost sanction in the environmental pollution. Layers of legal theory are carried out on theories that are used as a knife of analysis in the law enforcement issues. The legal philosophy layer emphasizes more on the discovery of legal values and principles, to comprehensively explain the nature of the integrity of criminal sanctions as primum remedium so that it can clarify every case of the environmental pollution that occurs. The problems analyzed focus on the environmental criminal law presenting regulations on the use of law in the context of criminal sanctions as primum remedium.

The approach used in this study is the philosophical approach, the statutory approach, the conceptual approach, and the case approach. A philosophical approach is used, to analyze legal issues as stated in the background of the problem by examining the existence and the development of the values of the nature of criminal sanctions as primum remedium and the legal functions that govern them so that the law principles can be developed as a legal concept that is aspired in the future (ius constituendum) in underlying legal norms that provide legal protection.

The statutory approach aims to examine and evaluate the applicable laws and regulations so that it can be found whether there is protection in terms of concepts and norms about the use of criminal law as primum remedium, to achieve this goal the researcher will identify, inventory the rule of law which specifically regulating the criminal sanctions as primum remedium in environmental pollution.

The conceptual approach aims to study the doctrines in the science of law that are expected to obtain ideas that gives birth to understandings, legal concepts, legal principles, in which it relates to the legal issues at hand. With this understanding, it can build legal arguments to answer legal issues with concepts related to the criminal sanctions as primum remedium.

The case approach aims to review court decisions related to the environmental pollution cases.

\section{Result Of Research}

\subsection{The Means for the Use of Environmental Law through Criminal Sanctions in the Environmental Crimes Field}

\subsubsection{The Unlawful Nature of Criminal Acts in the Environmental Field}

The unlawful nature has a very unique position in criminal law. Generally there has been an agreement from criminal law experts in seeing the nature of violating the law when it is associated with criminal acts. It is against the law absolutely for every crime. Andi Zainal Abidin said that: "one of the essential elements of offense is unlawful nature (wederrechttelijkheid) which is stated explicitly or not in a criminal law article, because it would be awkward if someone is convicted when committing unlawful acts". ${ }^{2}$

In the Criminal Code sometimes the word "against the law" is formulated explicitly in the offense formula and sometimes it is not explicitly formulated. If the word "against the law" is formulated and stated explicitly in the offense formula, such matter has an important meaning to provide protection or guarantees of not being

\footnotetext{
${ }^{1}$ Peter Mahmud uses the term legal issues to refer to legal problems. Legal issues according to Peter Mahmud: "is a problem that must be solved in legal research. Legal issues arise because of the two propositions that have a relationship, both functional, causality and one that emphasizes the other. Legal issues arise because of two legal propositions that are interconnected to one another. Legal issues can be developed from three domains of law, namely dogmatic law, legal theory, and legal philosophy. See Peter Mahmud Marzuki, Penelitian Hukum, Prenada Media, Cetakan ke-1, Jakarta, 2005, p. 56-86.

${ }^{2}$ Andi Zainal Abidin Farid, Hukum Pidana I, Sinar Grafika, Jakarta, 2007, p. 47.
} 
charged by those who are entitled or authorized to commit acts as formulated in the law. ${ }^{1}$ Only if a behavior can be formally formulated in the scope of the offense formula, but in general it is not actually a criminal offense, then the condition "against the law" is made one part of the offense formula. ${ }^{2}$ The consequence is the inclusion of "against the law" in the formulation of the offense causing the public prosecutor to prove this element.

If the word "against the law" are not stated or stated explicitly in the offense formula, then the element of unlawfulness does not need to be proven. The element of violating the law is that the act has automatically been proven by proving the prohibited act. ${ }^{3}$ In other words, although the word "against the law" is not mentioned in the formulation of the offense, then the nature of the act "against the law" is already in an offense. Based on this explanation there are some people who think that it is better if the elements "against the law" are not included in the formulation of the offense, because if included, it will make the prosecutor's task even harder, because he must prove in his indictment that the defendant's actions are "against the law".

In criminal law the word "unlawful nature" is a phrase that has four meanings. The four meanings are nature against common law, nature against specific law, nature against formal law, and nature against material law. Unlawful nature is defined as a general condition for the conviction of an act. Every crime in it must contain elements "against the law". While the specific unlawful nature of the word "against the law" is included in the offense formula. Violence is a written requirement for the conviction of an act. Unlawful nature is defined as being contrary to the law. Whereas the nature of violating material law is interpreted as contrary to the norms and values of society. ${ }^{4}$

3.1.2 The Criminal Act in Law Number 32 Year 2009 concerning Environmental Protection and Management There is a difference in the development of the criminal offense formulation in Law Number 4 of 1982 concerning Basic Provisions for Environmental Management, Law Number 23 of 1997 concerning Environmental Management and Law Number 32 of 2009 concerning Environmental Protection and Management, i.e in Act Number 4 of 1982 only recognizes material offenses, whereas in Act Number 23 of 1997 and Act Number 32 of 2009 the formulation of the offenses is material offenses and formal offenses even in Act Number 32 of 2009 has more formal offenses ${ }^{5}$, such as in Law Number 32 Year 2009 concerning Environmental Protection and Management:

1. The Conduct Actions that Result in Surpassing Ambient Air Quality Standards, Water Quality Standards,

Sea Water Quality Standards, or Environmental Damage Criteria.

The Article 98 paragraph (1), reads as follows:

"Any person who intentionally commits an act that results in exceedances of ambient air quality standards, water quality standards, seawater quality standards, or environmental damage criteria, shall be punished with imprisonment for a minimum of 3 (three) years and a maximum of 10 (ten) a year and a fine of at least Rp. 3,000,000,000.00 (three billion rupiah) and a maximum of Rp. 10,000,000,000.00 (ten billion rupiah)."

2. The Negligence Resulting in Overriding Ambient Air Quality Standards, Water Quality Standards, Sea

Water Quality Standards, or Environmental Damage Criteria.

The Article 99 paragraph (1) is formulated as follows:

"Anyone who, due to his negligence, has exceeded ambient air quality standards, water quality standards, sea water quality standards, or environmental damage criteria, shall be sentenced to a minimum of 1 (one) year prison term and a maximum of 3 (three) years and a fine at least Rp. 1,000,000,000.00 (one billion rupiah) and a maximum of Rp. 3,000,000,000.00 (three billion rupiah)."

3. Violating Wastewater Quality Standards, Emissions Quality Standards, or Disturbances Quality Standards The Article 100 states that:

"Everyone who violates the waste water quality standard, emission quality standard, or disturbance quality standard is convicted, with a maximum imprisonment of 3 (three) years and a maximum fine of Rp3,000,000,000.00 (three billion rupiah)."

4. Releasing and or Circulating Genetically Engineered Products to Environmental Media that Are Contrary to Legislation or Environmental Permits

The Article 101 explains that:

"Every person who releases and or circulates genetic engineering products to environmental media that is contrary to the laws and regulations or environmental permits as referred in Article 69 paragraph (1) letter $\mathrm{g} 1$, shall be sentenced to a minimum of 1 (one) year imprisonment and a maximum of 3 (three) years and a

\footnotetext{
${ }^{1}$ Roeslan, Saleh, Sifat Melawan Hukum dari Tindak Pidana, Aksara Baru, Jakarta, 1987, p. 1.

${ }^{2}$ Chairul Huda, Dari Tiada Pidana Tanpa Kesalahan Menuju Tiada Pertanggungjawaban Pidana Tanpa Kesalahan, Kencana, Jakarta, 2006, p. 50 .

${ }^{3}$ Tongat, Dasar-dasar Hukum Pidana Indonesia dalam Perspektif Pembaharuan, UMM Press, Malang, 2008, p. 211.

${ }^{4}$ Mahrus Ali, Ayu Izza Elvany, HUKUM PIDANA LINGKUNGAN (Sistem Pemidanaan Berbasis Konservasi Lingkungan Hidup), UII Press, Yogyakarta, 2014, p. 13.

${ }^{5}$ The difference between material offense and formal offense is: "a criminal threat to an act that has caused the result of an action (there is a causal relationship between an action and the result of an action)" Formal Offense is: the offense which is the formulation provides a criminal threat against a prohibited act, regardless of the consequences of prohibited acts."
} 
minimum fine of Rp. 1,000,000,000.00 (one billion rupiah) and a maximum of (three billion rupiah)."

5. Performing B3 Waste Management Without Permission

The Article 102 determines as follows:

"Any person who carries out B3 waste management without a permit as referred in Article 59 paragraph (4) 2 , shall be sentenced to a maximum of 1 (one) year imprisonment and a maximum of 3 (three) years and a fine of at least Rp1,000,000,000, 00 (one billion rupiah) and a maximum of Rp 3,000,000,000.00 (three billion rupiah)."

6. Generating B3 Waste and Not Doing Management

The Article 103 states as follows:

"Every person who produces B3 waste and does not carry out the management as referred in Article 593, shall be sentenced to a minimum of 1 (one) year imprisonment and a maximum of 3 (three) years and a minimum fine of Rp. 1,000,000,000.00 (one billion rupiah) and at most Rp. 3,000,000,000.00 (three billion rupiah)."

7. Dumping Waste and or Material to Environmental Media without Permission

The Article 104 is formulated as follows:

"Everyone who dumps waste and or materials into the environmental media without a permit as referred in Article 604, shall be sentenced to a maximum imprisonment of 3 (three) years and a maximum fine of Rp3,000,000,000.00 (three billion rupiah)."

8. Inserting Waste into Indonesian Territory

The Article 105 is formulated as follows:

"Every person who enters waste into the territory of the Unitary Republic of Indonesia as referred in Article 69 paragraph (1) letter $\mathrm{c} 5$ shall be sentenced to a maximum imprisonment of 4 (four) years and a maximum of 12 (twelve) years and a minimum fine of Rp. 4.000,000,000.00 (four billion rupiah) and a maximum of Rp. 12,000,000,000.00 (twelve billion rupiah)."

9. Inserting B3 Waste into the Territory of Indonesia

The Article 106 explicitly determines as follows:

"Every person who imports B3 waste into the territory of the Unitary Republic of Indonesia as referred in Article 69 paragraph (1) letter d6, shall be liable to a minimum of 5 (five) years imprisonment and a maximum of 15 (fifteen) years and a minimum fine Rp. 5,000,000,000.00 (five billion rupiah) and a maximum of Rp. 15,000,000,000.00 (fifteen billion rupiah)."

10. Entering B3 that is Prohibited According to Legislation in Indonesian Territory

The Article 107 reads as follows:

"Everyone who enters a B3 that is prohibited according to statutory regulations into the territory of the Unitary Republic of Indonesia as referred in Article 69 paragraph (1) letter b7, is sentenced to a maximum imprisonment of 5 (five) years and a maximum of 15 (fifteen) ) a year and a minimum fine of Rp. $5,000,000,000.00$ (five billion rupiah) and a maximum of Rp. 15,000,000,000.00 (fifteen billion rupiah)."

11. Do Land Burning

The Article 108 states that:

"Every person who burns land as referred in Article 69 paragraph (1) letter h8, shall be sentenced to a maximum imprisonment of 3 (three) years and a maximum of 10 (ten) years and a fine of at least Rp. 3,000,000,000.00 ( three billion rupiah) and a maximum of Rp. 10,000,000,000 (ten billion rupiah)."

12. Doing Businesses and or Activities without Having an Environmental Permit

The Article 109 reads as follows:

"Every person who conducts business and / or activities without having an environmental permit as referred to in Article 36 paragraph (1) 9, shall be sentenced to a maximum imprisonment of 1 (one) year and a maximum of 3 (three) years and a fine of at least Rp. 1.000,000,000.00 (one billion rupiah) and a maximum of Rp. 3,000,000,000.00 (three billion rupiah)."

13. Arranging Environmental Impact Assessment (EIA) without having a competency certificate EIA compiler The Article 110 regulates:

"Every person who compiles an EIA without possessing the competency certificate of an EIA compiler as referred in Article 69 paragraph (1) letter i10, shall be sentenced to a maximum imprisonment of 3 (three) years and a maximum fine of Rp. 3,000,000,000.00 (three billion rupiahs)."

14. Issuing Environmental Permits without Equipping with EIA or UKL-UPL

The Article 111 contains:

"The official granting an environmental permit that issues an environmental permit without being accompanied by environmental impact analysis or UKL-UPL as referred in Article 37 paragraph (1) shall be sentenced to a maximum imprisonment of 3 (three) years and a maximum fine of Rp. 3,000,000,000.00 (three billion rupiah)." 
15. Not Supervising Compliance with Business Responsible and or Activities towards Regulations and Environmental Permits.

The Article 112 states as follows:

"Every authorized official who intentionally does not supervise the observance of the person in charge of the business and or activity of the laws and environmental permits as referred in Article 7113 and Article 7214, which results in pollution and or environmental damage resulting in loss of human life, shall be sentenced to a maximum imprisonment of 1 (one) year or a maximum fine of Rp. 500,000,000.00 (five hundred million rupiah)."

16. Providing False Information, Misleading, Eliminating Information, Destroying Information, or Giving Incorrect Information Needed in Relation to Supervision and Law Enforcement relating to Environmental Protection and Management.

The formulation of Article 113 states that:

"Every person who provides false information, misleads, removes information, destroys information, or provides incorrect information needed in relation to supervision and law enforcement relating to environmental protection and management as referred in Article 69 paragraph (1) letter $\mathrm{j} 15$ sentenced to a maximum imprisonment of 1 (one) year and a maximum fine of Rp. 1,000,000,000.00 (one billion rupiah)."

17. Not Doing Government Coercion

The formula in offense Article 114 states that:

"Every person in charge of a business and or activity that does not carry out government coercion shall be liable to a maximum imprisonment of 1 (one) year and a maximum fine of Rp. 1,000,000,000.00 (one billion rupiah)."

18. Prevent, Obstruct, or Thwart the Execution of Duties of the Environmental Oversight Officer and or the Official Civil Servant Investigator.

The formula in offense Article 115 states that:

"Any person who intentionally prevents, obstructs, or frustrates the implementation of the duties of the environmental supervisor and or investigating civil servant official is sentenced to a maximum of 1 (one) year imprisonment and a maximum fine of Rp. 500,000,000.00 (five hundred million rupiah)."

\subsection{The Orientation of Legal Protection through Criminal Law as Primum Remedium}

\subsubsection{The Criminal System Based on Environmental Conservation as a Form of Legal Protection}

An important part of the penal system is to set sanctions. Its existence will provide direction and consideration regarding what should be used as sanctions in a criminal act to enforce the norms. ${ }^{1}$ The determination of the type of the crime, the imprisonment, and the implementation of the crime is closely related to the purpose of punishment. The problem of determining sanctions in criminal law, whatever the type and form of sanctions must be based and oriented to the goal of punishment. After the goal of punishment is determined, then the next step is determining the type and form of sanctions that are most appropriate for the perpetrators of crime. ${ }^{2}$ In addition, the sanctions imposed must be oriented in the same manner as the orientation of the criminal act committed so that the goal of punishment can be achieved.

Sanctions in criminal law as part of sanctions regulated in environmental legislation must also aim to realize these three things. However, sanctions in criminal law that are regulated in environmental legislation are currently not in accordance with the concept of environmental conservation. This is because sanctions in the criminal law regulated in the regulation have not been oriented to the implementation of life support systems protection, biodiversity preservation, and sustainable use.

To determine the type of sanctions that need to be regulated and imposed on the perpetrators of criminal acts in the environmental field also needs to pay attention to the main victims of the crime. The main victims of the crime in the environment are the environment itself, the state and society. By knowing the victim, the criminal sanction imposed should be able to repair or restore the environment to its original state before the crime was committed, and then it provides compensation to the injured party both the state and or the community. For example, restoring forests to their original state as before criminal acts is an appropriate sanction for perpetrators of forestry crime so that it can cause a deterrent effect and preserve the forest. With these sanctions, the state also avoids the possibility of suffering losses due to the commission of the crime.

Criminal fines and sanctions are appropriate forms of sanctions to be imposed on criminal offenders in the environmental field. Even though the imprisonment is possible for perpetrators of environmental crimes, criminal fines take precedence because they have an economic character. In addition, the position of financial sanctions is higher than non-financial sanctions so that non-financial sanctions should not be used unless

\footnotetext{
${ }^{1}$ Teguh Prasetyo dan Abdul Halim Barkatullah, Politik Hukum Pidana Kajian Kebijakan Kriminalisasi dan Dekriminalisasi, Pustaka Pelajar, Yogyakarta, 2005, p. 82.

${ }^{2}$ George, A. N, 1989, Minimizing Risk of Loss From Environmental Laws, published on The Banking Law Journal Vol. 108 No. 4 JulyAugust.
} 
financial sanctions cannot be prevented properly. New non-financial sanctions are needed to prevent criminal offenses when financial sanctions are not sufficient for the task.

Fines are payments of a sum of money from perpetrators to the state while imprisonment means the price of freedom, production and income used in the criminal justice system. ${ }^{1}$ In its history, criminal fines have been used in criminal law for centuries. Criminal fines are actually the oldest penalties and they are older than prison sentences. Criminal fines were originally civil relations. When someone is harmed, he may sue for damages. For the amount, it depends on the amount of loss suffered and the person's social status. Criminal fines are the third main type of criminal law in Indonesian criminal law which basically can only be dropped for adults. The interesting thing in criminal fines includes the stipulation of the amount of fines based on categories and payment of fines which can be paid in installments.

There are several criminal acts carried out in a planned manner and aimed at obtaining profits, for example namely environmental pollution which is often carried out by industries aimed at obtaining profits. In environmental legislation, there is a lack of clarity in differentiating the types of criminal sanctions, especially additional crimes from the types of sanctions actions which often placed as (additional) criminal sanctions, and vice versa. In Law Number 32 of 2009 concerning Environmental Protection and Management, sanctions for acts are placed as additional crimes. Consequently, it cannot be handed down alone without concurrent with the main criminal. In addition, additional criminal offenses are basically facultative, in the sense that these penalties can be imposed in matters determined by law, but this is not a requirement. ${ }^{2}$

Sanctions for these facultative actions can hamper the implementation of environmental conservation. This is because sanctions are not always imposed on environmental offenders. Whereas its existence actually includes sanctions that should be prioritized to be applied because the form is in the form of acts which aimed directly at improving and or restoring the environment to its original state before the occurrence of criminal acts in order to realize the environmental conservation.

Sanctions for actions regulated in environmental law should be imperative for the realization of a penal system based on environmental conservation. These sanctions also can not only be imposed on criminal offenders in the form of corporations but also humans. Because, a criminal offense in the form of a person can commit a criminal offense in the environmental field whose impact is the same as criminal offense committed by a corporation.

In some environmental laws, judges can impose direct action on polluters who have been convicted, such as the obligation to repair the damage that they have done. The aim is that they realize their mistakes and can improve themselves so that they become a law-abiding citizen. Perpetrators of criminal offenses convicted to improve the environment that have been polluted and or damaged due to their actions, so that they can know firsthand the difficulty of environmental recovery to its original condition before the occurrence of the crime and the negative impact of the act.

Perpetrators of the river water pollution crime, if convicted in the form of restoring river water to its original condition before the occurrence of pollution, they can find out how difficult it is to restore the condition of river water to its original state. They can also know the damage to the river water ecosystem directly, like many fishes which are a source of income will die.

3.2.2 The Pattern of Criminal Threats Weighting As the Most Important Part of the Primum Remedium Principle Theoretically, the weighting of criminal threats leads to two aspects, namely the quality aspect and the quantity aspect. The quality aspect is defined as a weighting that occurs because of a change from one type of lighter criminal to another type of heavier criminal. The types of principal crimes in the provisions of Article 10 of the Criminal Code need to be used as a benchmark whether one type of criminal has a lower or higher position than other types of the crime. If someone is given an indictment of imprisonment, but the judge's decision against the defendant on capital punishment is related to the quality aspect of criminal prosecution because there is a change from one type of lighter criminal to a heavier type of criminal.

In the context of a penal system based on environmental conservation, it experiences a change from both aspects of the quantity and the quality which point to a change from one type of lighter criminal to a more severe types of criminal. This concept clearly creates problems if it is used as a theoretical basis for the weighting of criminal threats based on environmental conservation. Because, all types of crimes such as capital punishment, imprisonment, and confinement (except criminal fines), are types of crimes that are not directly related to environmental conservation. These types of crimes may only be dropped if the victim of a crime is human, but if the victim is a living environment, the type of crime cannot be dropped.

In terms of quantity, the pattern of weighting criminal threats mentioned in the previous section is still unable to protect the existence of the environment as victims of criminal acts. This is because even though there is a weighting of imprisonment from 10 years to 20 years, there is no relationship with the environment that is

\footnotetext{
${ }^{1}$ Op.cit, p. 167

${ }^{2}$ M. Sholehuddin, Sistem Sanksi Dalam Hukum Pidana, Rajagrafindo Persada, Jakarta, 2004, p. 17.
} 
directly damaged by the perpetrators' actions.

One of the reasons is the difference in orientation of legal protection between humans and the environment as victims of the crime. If the victim is a human it is very relevant if criminal charges are used in terms of the quality and the quantity. But if the victim is the environment, then both of the concepts cannot be applied. Because of the differences in the orientation of legal protection, the types of sanctions that are threatened become vary, including the pattern of imposing criminal threats.

In this connection, the types of sanctions that can be applied to perpetrators who are proven to have committed criminal acts which caused losses or damage to the environment, are more in the form of sanctions actions (treatment), such as seizing profits derived from criminal acts, closing all or part of a business place and or activities, repairing as a result of crime, obligation to do what was neglected without rights, and or company placement under submission. Even if criminal sanctions (punishment) will be applied, this is limited to criminal fines.

The change in the concept of a criminal charge from a quality oriented environment conservation has implications for the inaccuracy of appropriating the profit obtained from a crime, closing all or part of a place of business and or activity, repairing due to a criminal act, the obligation to do what was neglected without rights and or company placement under the capabilities which contained in the Environmental Protection and Management Act as an additional crime. Based on quality aspect, the forms of sanctions are more severe compared to imprisonment, confinement and fines. For example, when a person is sanctioned in the form of an obligation to correct all the consequences of a criminal offense that is because it has been proven to cause severe damage to the environment, the costs incurred are far greater than being subjected to a criminal fine of 5 billion. Therefore, these forms of sanctions should not be placed as additional crimes. Even if it is still placed as an additional criminal, there must be a provision that the additional criminal can be imposed without combining the main criminal by following the Wet Vermogenssancties (the Law on Wealth Crimes or the Sanction Act on Dutch Property). ${ }^{1}$

According to quantity aspect, the pattern of weighting criminal threats based on environmental conservation is only possible if the criminal form is criminal fines. However, the pattern used is the imposition of criminal threats with a multiplied system by not formulating the nominal amount of fines in the formulation of each article in which there is a weighting of criminal threats. With this pattern the amount of fines that must be paid by the perpetrators must be greater or heavier than the crime committed as in the theory of criminal prevention. In addition, there must be a regulation that determines that the amount of the fines paid by the state to be used directly in the environmental conservation efforts. If this is not regulated, the pattern of weighting the threat of fines with the multiplex system will not be related to environmental conservation.

\section{Conclusion}

The meaning of Primum Remedium as an instrument to deal with criminal acts is to increase the awareness of the development of human rights that bring changes to a criminal responsibility which is no longer ultimum remedium but primum remedium. Law of the Republic of Indonesia Number 32 Year 2009 concerning Environmental Protection and Management is a legal instrument established to protect the country in the environmental side. Therefore, it is a necessity for all human beings to create a healthy, clean and insightful environment, because people's awareness of the environment is part of human rights. The emphasis of justice in the Law of the Republic of Indonesia Number 32 Year 2009 concerning Environmental Protection and Management is clearly regulated in the articles. Law of the Republic of Indonesia Number 32 Year 2009 concerning Protection and Management of the Environment is an instrument to complete the previous legislation on the environmental sector which related to the weakness of the substance from Law Number 23 of 1997 concerning Environmental Management. The formulation of criminal provisions in Act number 32 of 2009 is the development and revision of the formulation of criminal provisions in Act Number 23 of 1997 and Act Number 4 of 1982. If Act Number 4 of 1982 only contains formulations of criminal provisions which are material offenses, then Law Number 23 of 1997 contains formulations of material offenses and formal offenses.

The substance of environmental law includes a number of legal provisions concerning and relating to the efforts of preventing and overcoming environmental problems. Regarding the field of environmental law, it seems that among the scholars, there is no common view. Enforcement of criminal sanctions in the Law of the Republic of Indonesia Number 32 Year 2009 is to place criminal law not as an ultimum remedium sanction but rather as primum remedium, limited to environmental crimes which related to strict liability.

\section{References}

Amsyari, F., Prinsip-prinsip Masalah Pencemaran Lingkungan, Ghalia Indonesia, Andi Zainal Abidin Farid, Hukum Pidana I, Sinar Grafika, Jakarta, 2007.

\footnotetext{
${ }^{1}$ Suhariyono, Pembaruan Pidana Denda, Rajagrafindo Persada, Jakarta, 2012, p. 41
} 
Chairul Huda, Dari Tiada Pidana Tanpa Kesalahan Menuju Tiada Pertanggungjawaban Pidana Tanpa Kesalahan, Kencana, Jakarta, 2006.

Hakim., A., Pendayagunaan Hukum dalam Pencegahan, Pencemaran Lingkungan akibat Limbah Industri, LIPI, Jakarta, 1992.

M. Sholehuddin, Sistem Sanksi Dalam Hukum Pidana, Rajagrafindo Persada, Jakarta, 2004, p. 17.

Mahrus Ali, Ayu Izza Elvany, HUKUM PIDANA LINGKUNGAN (Sistem Pemidanaan Berbasis Konservasi Lingkungan Hidup), UII Press, Yogyakarta, 2014.

Peter Mahmud Marzuki, Penelitian Hukum, Prenada Media, Cetakan ke-1, Jakarta, 2005

Subhi Mahmassani, Konsep Dasar Hak- hak Asasi Manusia, Suatu Perbandingan Dalam Syariat Islam dan Perundang- undangan Modern, Tinta Mas, Jakarta, 1993.

Suhariyono, Pembaruan Pidana Denda, Rajagrafindo Persada, Jakarta, 2012

Teguh Prasetyo dan Abdul Halim Barkatullah, Politik Hukum Pidana Kajian Kebijakan Kriminalisasi dan Dekriminalisasi, Pustaka Pelajar, Yogyakarta, 2005

Tongat, Dasar-dasar Hukum Pidana Indonesia dalam Perspektif Pembaharuan, UMM Press, Malang, 2008.

\section{Article and Journal}

Agung Wardana, Perusakan Lingkungan Sebagai Pelanggaran HAM, article, 2007

Dadang Sudarja, Reformasi Pengelolaan Lingkungan Hidup, article, on the discussion of Membangun Gerakan Lingkungan Skepo, Walhi, 2007

George, A. N, 1989, Minimizing Risk of Loss From Environmental Laws, published on The Banking Law Journal Vol. 108 No. 4 July-August.

\section{The Constitutions}

The 1945 Constitution of the Republic of Indonesia

Law Number 1 of 1946 concerning the Criminal Code (KUHP)

Law Number 4 of 1982 concerning Basic Provisions for Environmental Management.

Law Number 23 of 1997 concerning Environmental Management.

Law Number 32 of 2009 concerning Environmental Protection and Management.

Law No. 39/1999 concerning Human Rights 